Intersections

Canadian Journal of Music

Revue canadienne de musique
Intersections CANADAN TOURAA OP NUSIC

\title{
Analytical Approaches to World Music 1, no. 1.
} http://aawmjournal.com/

\section{Michael B. MacDonald}

Volume 31, numéro 1, 2010

URI : https://id.erudit.org/iderudit/1009293ar

DOI : https://doi.org/10.7202/1009293ar

Aller au sommaire du numéro

Éditeur(s)

Canadian University Music Society / Société de musique des universités canadiennes

ISSN

1911-0146 (imprimé)

1918-512X (numérique)

Découvrir la revue

Citer ce compte rendu

MacDonald, M. B. (2010). Compte rendu de [Analytical Approaches to World

Music 1, no. 1. http://aawmjournal.com/]. Intersections, 31(1), 194-198.

https://doi.org/10.7202/1009293ar

All Rights Reserved (C Canadian University Music Society / Société de musique des universités canadiennes, 2012
Ce document est protégé par la loi sur le droit d'auteur. L'utilisation des services d'Érudit (y compris la reproduction) est assujettie à sa politique d'utilisation que vous pouvez consulter en ligne.

https://apropos.erudit.org/fr/usagers/politique-dutilisation/ 


\section{WORKs Cited}

Agawu, Kofi. 1991. Playing with Signs: A Semiotic Interpretation of Classic Music. Princeton, NJ: Princeton University Press.

Capuzzo, Guy. 2004. "Neo-Riemannian Theory and the Analysis of Pop-Rock Music." Music Theory Spectrum 26 (2), 177-99.

Chatman, Seymour. 1980. Story and Discourse: Narrative Structure in Fiction and Film. New York: Cornell University Press.

Ratner, Leonard. 1980. Classic Music: Expression, Form and Style. New York: Schirmer.

Sniader Lanser, Susan. 1981. The Narrative Act: Point of View in Prose Fiction. Princeton: Princeton University Press.

.1992. Fictions of Authority: Women Writers and Narrative Voice. Ithaca, NY: Cornell University Press.

JADA WATSON

Analytical Approaches to World Music 1, no. 1. http://aawmjournal.com/.

The journal Analytical Approaches to World Music begs an explication of what is implicit in its title. While what is meant by world music has become largely self-evident, analytical approaches is less so. My first response of course was to wonder who was practising non-analytical approaches to world music. But given the high-profile scholars on this new journal's editorial and advisory boards, analytical must suggest something more than the act of analysis.

The journal is an extension of the First International Conference on Analytical Approaches to World Music (AAWM) held at the University of Massachusetts-Amherst in February 2010. The conference brought together music theorists, ethnomusicologists, musicologists, cognitive psychologists, computer scientists, and mathematicians to explore new and novel approaches to the analytical study of world music. The excitement they generated spilled out onto the electronic pages of a new organ, the AAWM online journal. This premiere issue was published in 2011 and includes a welcome introduction from editors Lawrence Shuster and Rob Schultz, along with six diverse and challenging articles.

Perhaps analytical in this context is related to the way music scholarship is practised. Ethnomusicology, borrowing as it has from anthropological studies and using ethnography as a tool, has not spent as much time as some would like delving into the musicological questions presented by many of the world's musical systems. Some may suggests that ethnomusicology has become context driven at the cost of musicological inquiry. Perhaps analytical also suggests a musicological intervention into ethnomusicology and this journal as an opportunity to reimagine the relationship between ethnomusicology, musicology, and music theory-making a collective musicological project to document the ethnosphere. 
Wade Davis, the Canadian anthropologist, ethno-botanist, and National Geographic Explorer-in-Residence, coined ethnosphere as "the sum total of all thoughts and intuitions, myths and beliefs, ideas and inspirations brought into being by the human imagination since the dawn of consciousness" $(2009,2)$. Davis offered ethnosphere as a corollary to the term biosphere-the biological foundations for life. The ethnosphere is the cultural web of life, marked by astonishing diversity, and the basis for social, cultural, and individual health. Davis has spent the last decade pointing out that cultural diversity is suffering far greater loss than even the tragic and well-publicized losses in earth's biodiversity. Who is responsible to protect global cultural diversity in music making, and if one wanted to, how would one go about it? How do we square cultural diversity, global musical inquiry, industrial development, and cultural preservation with our job as music researchers and educators? Perhaps it is here that a journal like Analytical Approaches to World Music may be situated-taking the music of the world seriously as musical systems worth detailed musicological inquiry and theory making as a step towards documenting and sharing the vastness, and sophistication, of the world's musics. And if this is the mission of the journal, it needs to be made clear as there are already so many journals vying for attention.

Robert Morris's “Tana Varnam-s: An Entry into Raga Delineation in Carnatic Music" enters into this territory and argues that there is a methodological lack of both raga description and pedagogy, and this lack slows scholarly analysis. After an introduction to Carnatic music pedagogy, in both its traditional and contemporary settings, Morris explains the use of the varnams as graded compositions to introduce the student to the intricacies of the ragas and the function of the rhythmic elements of the tala. Following an introduction to Indian music notation, which makes the schematic form of the notational system evident, the reader is introduced to audio examples of music lessons. Morris presents an analytical methodology to explore Carnatic music developed from the chief pedagogical aids, recordings, and notation systems. The embedded music examples are an excellent addition to this article and the journal generally, although they could open in a new window instead of taking the reader away from the section of the paper in question.

In the second article, Sarah Weiss skilfully introduces the reader to the conceptual challenges presented in Javanese grimingan, a solo instrumental music for the gender performed to accompany the dhalang, or puppeteer, at times when the otherwise more popular gamelan is not performed. Weiss deftly constructs a method to capture the relative formlessness of grimingan and illustrates the aural nature of grimingan, and the informal education that accompanies it, which has the effect of creating lineage systems where players from the same teacher have similar approaches. Weiss reminds us that this was also once true of gamelan before the advent of conservatories and radio broadcasts.

In David Locke's “The Metric Matrix: Simultaneous Multidimensionality in African Music" we are introduced to the idea that many types of African music, deeply woven into the fabric of composition, have an aesthetic value placed 
upon what Locke calls "simultaneous multidimensionality." To explain this he introduces the very exciting concept of metric matrix and explains it as he expertly navigates rhythmically complex aesthetic frameworks. Two difficulties emerged in the execution of the paper, however. Aesthetic concepts are socially and environmentally embedded, as John Dewey (1934) has long ago illustrated and Christopher Small (1996) and Arnold Berleant (1992, 2000, 2010) have more recently expanded. Losing this context does not help the reader get closer to the aesthetic realities of simultaneous multidimensionality. How is this concept discussed in the language of formal and informal pedagogy, or where does it emerge in ethnographic work by African scholars?

Richard Widdess's discussion of implicit raga knowledge in the Kathmandu valley speaks to Robert Morris's piece on Carnatic music and to Locke's as he traces a narrative line across this introductory journal. Widdess draws the reader into a great story that begins with a description of the function of song as an invocation to spirits to dance, but we hear nothing more from these visiting spirits as the paper progresses. After a transcription analysis, Widdess is able to illustrate that raga structure remains fairly consistent across a variety of different neighbourhoods of Bhaktapur and that oral transmission is more consistent than expected. After a paragraph-length discussion of transmission, the article closes with a call for further research into the social contexts, cognitive processes, histories, and meanings for the performers.

The collection takes a surprising turn with the first of Jan Rahn's 2-part “The Hurrian Pieces, ca. 1350 BCE." This article attempts an in-depth statistically oriented study of the empirical tendencies and relative uniformity of the surviving pieces in this idiom. This study seeks to develop an empirical strategy to connect string assignment to notes, which will happen in the second part of the study. This work is likely very important to archeo-musicologists and music theorists interested in empirical methods, but the complexity and report style made understanding the argument very difficult, as I felt that the author was responding to arguments in a field on which I was uninformed.

In "Temporal Transformations in Cross-Cultural Perspective," Michael Tenzer, interested to find a place where music theory and ethnomusicology can speak together, explores how time is experienced cross-culturally through baroque, Carnatic, and Balinese musics. Tenzer focuses on "the technique of temporal augmentation," which "interacts with other aspects of musical structure in three works from different cultures." The most engaging aspect of this article is the author's honest and open desire to share something that he has learned. He admits that the approach he is about to take-transcribing all of the examples in Western notation-is problematic and yet he moves on with the project undeterred. After a journey through these three examples, Tenzer opens a comparison section, quoting Jonathan Kramer quoting Marvin Mindky that music is a form of play through which we learn about the world and specifically about time.

In the concluding pages Tenzer speaks directly to my expectation of this journal, so is worth quoting: "To many ethnomusicologists, moreover, this venture remains fraught because it overlooks indigenous ways of knowing. 
Counter-hegemonies are what we should be promoting, and instead of building our own synthetic apparatus we should concentrate on fostering understanding of musicians everywhere who have far more trying issues than what kinds of music analysis to do" (172).

Tenzer forwards another perspective. Perhaps we have bought into the "west and the rest" discourse too completely and have lost sight of the real issue, which is, according to Tenzer, "the cosmopolitan musician." Tenzer's final paragraphs are the authoritative ones of the journal: he tells us that while his three examples are from different musical cultures, he did not feel as if he were crossing cultures in discussing them. He is comfortable in his tri-musicality. Here the tone changes somewhat from his more conciliatory opening: "Yet even if their internal arguments are sound (and I hope they are), a reader without expertise would be in no position to confirm their salience. Readers must proceed on faith to a certain extent, and accept that the more one knows the culture the more one can critique the analysis." He goes on to assert that "it may seem like a cop-out to offer a supposedly cross-cultural system only to devolve back to the trump card of cultural specificity and insider knowledge. However I think this is not only inevitable but desirable, and it reflects how complex and irrational insider/outsider relations are" (174).

To help contextualize this position I turned to the foreword of Michael Tenzer's 2006 edited collection Analytical Studies in World Music in search of a mission statement for the journal Analytical Approaches to World Music. I expected a broad use of the notion of analysis, collecting perhaps, ways of engaging music beyond empirical approaches, and even beyond accepted musicological approaches. I was expecting this journal to begin a response to a dilemma the writer and activist bell hooks $(1990,112)$ has noted: "Many underclass black people who do not know conventional aesthetic theoretical language are thinking critically about aesthetics. The richness of their thoughts is rarely documented in books." This is a reasonable expectation, as Tenzer defines analysis as the "encounter between the hierarchy-seeking mind and the music-sound event" $(2006,6)$ and encounter, after critical musicology, might take into account cultural power, global economic inequality, and postcolonial movements as important background for analytical development. Further, I wonder how intercultural musicology and empirical musicology played a role in the journal's understanding of analytical approaches.

Like hooks, I just don't see why one would not make space for the voices of the traditional musicians who indeed have sophisticated cognitive and conceptual methods for the transmission and performance of the music they practise. And since methods of transmission exist, there is an opportunity for theorists to engage with these systemic vocabularies on their own terms. Perhaps Agawu (1995), Feld (1982), and Seeger (2004) have done this with their excellent studies of the Ewe, Kaluli, and Suya music making. Even such simple and seemingly transparent tools like notation, used widely in this journal, may have unrecognized psychological effects. John Sloboda $(1985,242)$ has argued that notation is not neutral: "Encouraging the separation of the content of an utterance from its context, makes it easier for an utterance to be treated as a 'thing in itself."' The 
uniqueness of this new journal could be to widen the role of analyst, extending it from the professional (ethno)musicologists and theorists to include the world musicians whose deep thoughts and meaningful histories may offer rich insights and challenging epistemological and ontological perspectives, no doubt expanding our current understanding of what it means to be analytical.

\section{WORKs Cited}

Agawu, Kofi. 1995. African Rhythm: A Northern Ewe Perspective. New York: Cambridge University Press.

Berleant, Arnold. 1992. The Aesthetics of Environment. Philadelphia, PA: Temple University Press.

-2000. The Aesthetic Field. New York: Cybereditions.

- 2010. Sensibility and Sense: The Aesthetic Transformation of the Human World. Charlottesville, VA: Imprint Academic.

Davis, Wade. 2009. The Wayfinders: Why Ancient Wisdom Matters in the Modern World. Toronto: House of Anasi Press.

Dewey, John. 1934. Art as Experience. New York: Capricorn Books.

Feld, Steven. 1982. Sound and Sentiment: Birds, Weeping, Poetics, and Song in Kaluli Expression. 2nd ed. Philadelphia, PA: University of Pennsylvania Press.

hooks, bell. 1990. Yearning: Race, Gender, and Cultural Politics. Boston, MA: South End Press.

Seeger, Anthony 2004. Why Suya Sing: A Musical Anthropology of an Amazonian People. Chicago: University of Illinois Press.

Sloboda, John A. 1985. The Musical Mind: The Cognitive Psychology of Music. New York: Oxford University Press.

Small, Christopher. 1996. Music, Society, Education. Hanover, NH: Weslyan University Press.

Tenzer, Michael. 2006. Analytical Studies in World Music. New York: Oxford University Press.

Michael B. MacDonald

Mondher Ayari et Hamdi Makhlouf, dir. 2010. Musique, signification et émotion. Sampzon : Delatour France, 392 p. ISBN 987-2-7521-0077-1 (couverture souple).

Le lien musique-signification-émotion est un des champs d'études musicologiques les plus emblématiques, tout en étant possiblement un des plus énigmatiques. À ma connaissance, il n'existe pas, encore aujourd'hui, de consensus permettant d'attester d'un lien sans équivoque, si ce n'est apodictique, entre ces trois schèmes, surtout considérant que la conception de ce lien peut varier selon le domaine d'expertise, le chercheur, le musicologue ou même l'interprète qui l'aborde. Le débat est donc loin d'être clos. Cette parution, sous la direction de 